\title{
Identifying the Motives for User Participation in Information System Projects
}

\author{
Rahul Thakurta \\ Xavier Institute of Management Bhubaneswar (XIMB) \\ Xavier University, India \\ rahul@ximb.ac.in
}

\begin{abstract}
The importance of user participation in information systems development has received a lot of attention from researchers. While prior research efforts have clarified many issues related to user participation, the reasons behind user's participation in IS projects are still unexplored. The study raises the question of what are the different motives for user participation in IS project. The investigation uses multivariate data analysis techniques to propose a dimensional representation of user participation motives in the context of IS projects. The results identify five user participation motives i.e. nature of association, techno centric activity, user centric activity, user interest, and project importance. The results of the study contribute to both theory and practice by segregating the different dimensions of user participation motives that may serve as cues in designing effective user integration mechanisms.
\end{abstract}

Keywords: user participation; information systems development; exploratory factor analysis

Citation: Thakurta, R. (2017). "Identifying the Motives for User Participation in Information System Projects," Pacific Asia Journal of the Association for Information Systems, 9(3), pp. 6796. 


\section{Introduction}

The participation of users in information systems (IS) development has been an important topic of research since 1960s (Swanson, 1974). Several academicians and consultants recommend user participation in IS development as an effective practice to achieve various favourable outcomes, including enhanced user satisfaction and increased system quality (Ives \& Olson, 1984; Markus \& Mao, 2004). However, it has been observed that user participation is not enough to guarantee achievement of desired objectives, for example, system success chances (Abelein \& Paech, 2013; Bano \& Zowghi, 2015; He \& King, 2008). Certain studies have also argued that participation of users might actually impair the performance of IS development projects (Brodbeck, 2001; Heinbokel, Sonnentag, Frese, Stolte, \& Brodbeck, 1996). It is therefore imperative to understand the reasons behind user participation in IS projects.

The typical understanding of a user is someone who would be actually using the system and her/his work and environment in some way would be effected by the system (Bano \& Zowghi, 2015). Various categories of IS users can be identified. The first category relates to the hands-on users who directly interact with the system by providing the inputs and receiving the outputs. The second category are the indirect end users who do not interact with the systems but benefit from the results of these systems. The third category of users have the management responsibilities for application systems. The oversee investment in the development or use of the system. The fourth category of users are the senior managers having responsibility of evaluating organization's exposure to risk from the systems failure (Senn, 1989). The third and fourth category of users are also referred as business users and is the focal entity of our investigation in this research.
In relation to business users', existing research has identified the contingencies that influence user's participation in IS projects (Doll \& Torkzadeh, 1989; Ives \& Olson, 1984; Mao \& Markus, 2004). These contingencies facilitate or hinder the process of user participation in IS projects but lacks explanatory power when understanding the reasons of user participation in various levels is the object of inquiry (Maail, Kurnia, \& Chang, 2010). Further, the reported instances of users' participation in IS projects are often found to be guided by politically motivated justifications driving the need to involve users (Howcroft \& Wilson, 2003). Hence understanding the real reasons behind user participation might provide more clarity on the ensuing dynamics between project users and the project development team during IS development.

Hence this paper reports on an investigation of the reasons of user participation in IS projects. An appreciation of these reasons are important as (1) this will indicate the various motives behind users' participation in IS projects; (2) this will provide indication of the users' own needs of participating in the concerned IS projects and not some other's viewpoint concerning user participation in projects; (3) this may result in a better engagement of the users during the project; (4) this may provide project managers with various handles in order to effectively manage the process of user participation in a project. These specific indicators to designing user participation procedures are likely to be more useful to the practitioners in comparison to ad-hoc and intuition based approaches.

This study raises the following research question: What are the various motives for user participation in IS project? The objective of the study is to arrive at a characterization of user participation motives in the context of IS projects. The term "motive" (noun) refers to a reason for doing something (Babcock \& Gove, 1993). Hence we define user participation motive as the reason for a user to participate in a 
project. We focus on only IS projects, specifically the traditional software development projects where-in (business) user participation may take place at any point based on the project status and requirements. Hence considerations of enduser development, open source software (OSS) development, etc. are outside the purview of this research. We carry out our investigation using multivariate data analysis techniques to propose a dimensional representation of user participation motives in the context of IS projects.

The paper is organized in the following sections: The next section presents a review on user participation that informs the current research. Subsequently, we discuss our research methods in detail. We then present our research results concerning the representation of the user participation motives in IS projects. A reliability and validity analysis of our proposed measures is presented in the following section. The results are then subsequently discussed. The final section concludes the study by summarizing the findings, discussing the limitation, and providing suggestions for future work.

\section{Review of Work and Theoretical Background}

In our review of user participation research, we first address the notion and characterization of user participation. In the context of business users' participation, we then discuss the effects of user participation, and user participation contingencies. The theoretical backdrop explaining participation motivation is presented subsequently informing the current research.

\section{Notion of User Participation}

"Participation" has been used inconsistently in literature as a synonym for "involvement" and "engagement". A clear demarcation between user participation and user involvement has been given in Barki and Hartwick (1991). User participation has been defined as "... behaviors and activities that the target users or their representatives perform during the system development process" (Barki \& Hartwick, 1991) and user involvement as "a subjective psychological state reflecting the importance and personal relevance of a system to the user" (Barki \& Hartwick, 1989). Hence it is not necessary that the users who are involved in the project should also participate and perform activities. The term "engagement" has been used synonymously in the literature as an additional term to both concepts of involvement and participation (Hwang \& Thorn, 1999).

User participation takes place when the end user takes an active part in the development or design process together with the designer (Hope \& Amdahl, 2011). User participation has been the core topic of IS and Human Computer Interaction $(\mathrm{HCl})$ research (Swanson, 1974). The IS development literature has examined user participation predominantly in the context of business users participating with IS professionals in the planning, design, and implementation of an information system (Howcroft \& Wilson, 2003; Markus \& Mao, 2004). Studies of user participation have recognized the following user participation schools viz. Participatory Design (PD) (e.g., Kensing \& Blomberg, 1998; Mumford, 1981; Schuler \& Namioka, 1993), User-Centred Design (UCD) (e.g., livari \& livari, 2011; Norman, 1986) and User Innovation (UI) (e.g., Kujala \& Kauppinen, 2004; Lawrence \& Low, 1993; Von Hippel, 1986). The PD approach traces its roots to the Scandinavian design tradition (Lawrence \& Low, 1993), and emphasize the need to include the users as a part of the decision making process e.g. through workshops, prototype evaluations etc. (Kujala, 2003). UCD emerged in the late 1970s and early 1980 s, and places users into the center of the design. Here users are not involved in decisions concerning design and instead other methods are employed (Kujala, 2003). 
Lastly, UI refers to innovation by lead users who have strong needs that may be common to other users in the future (Von Hippel, 1986), the overall goal being to provide innovative systems functionality.

\section{Characterization of User Participation}

Barki and Hartwick (1994) had proposed a 20 item scale for measuring user participation. These 20 items assessed the responsibilities and activities carried out by the users during participation in IS development, and comprised of the following three dimensions: user-IS relationship, responsibility, and hands-onactivities. Cavaye (1995) proposed a characterization of user participation in six dimensions as shown in Table $1^{1}$.

The representation indicates that user participation is not a definite, harmonized concept but can occur at different levels in various types (Bachore \& Zhou, 2009). Organizations can choose a particular system development approach which represents a specific level of user participation (Mattia \& Weistroffer, 2008). Some organization might start with a lower level of user participation and move up the continuum, while others might choose to employ different levels of user participation for different projects. The variation in the level of user participation during project execution has been also explained by Barki and Hartwick (1991). The authors indicate that the process of user engagement during a project takes place in two stages. In the first stage, user participation is guided by factors characterizing the system and the users. This leads to formation of beliefs about the system, which further moderates the intensity of engagement in the second stage and influence the project outcome.

Mumford (1979) identifies three types of user participation as consultative, representative, and consensus. In consultative type, design decisions are made by the systems group, but the objectives and form of the system are influenced by the needs, especially job satisfaction needs, of the user department. In representative type, all levels and functions of the affected user group are represented in the system design team. Finally, in consensus type, an attempt is made to involve all workers in the user department, at least through communications and consultation, throughout the system design process.

\begin{tabular}{|l|l|}
\hline Table 1 - User Participation Dimensions (Cavaye, 1995) \\
\hline Dimensions & Possible Values \\
\hline Type & All users, representatives of users \\
\hline Degree & Advisory capacity, sign-off responsibility, part or team, full responsibility \\
\hline Content & Technical design, social and technical design \\
\hline Extent & Project, requirements definition, building, testing \\
\hline Formality & Formal, informal \\
\hline Influence & Input ignored, contribution considered, input taken seriously \\
\hline
\end{tabular}

1 Clement (1994) further acknowledges the political dimension of user participation in user engagement proposes the following two categories i.e. functional and democratic. For functional empowerment, the users should be able to carry out their work to their own satisfaction and in an effective, efficient, and economical manner and for democratic empowerment the users should have the mandate to participate in decision-making including the design and development of software and IS. 


\section{Effects of User Participation}

Studies have reported inconsistent findings on the effects of user participation in IS projects (Bachore \& Zhou, 2009; Harris \& Weistroffer, 2009; Hwang \& Thorn, 1999; Spears \& Barki, 2010). It has been observed that user participation in IS projects is not enough to guarantee achievement of intended project objectives (e.g. IS success) and the desired benefits (Bano \& Zowghi, 2015; He \& King, 2008; Shen \& Khalifa, 2013; Symon \& Clegg, 2005). The benefits of user participation in IS projects are identified as accurate specification of requirements (Maiden \& Rugg, 1996), improved work organisation and industrial democracy (Cherry \& Macredie, 1999), better user interfaces (Smith \& Dunckley, 2002), decreased user resistance (Bjerknes \& Bratteteig, 1995), and higher user commitment, assistance, and satisfaction (Bakalova \& Daneva, 2011; Markus, 1983). The drawbacks of user participation in IS projects has been traced to inappropriate selection to approaches leading to counterproductive or demanding situations (McKeen \& Guimaraes, 1997), user-developer conflicts (Wilson, Bekker, Johnson, \& Johnson, 1996), difficulties in sustaining continued use of participative approaches (Hirschheim, 1983), with all these having a negative influence on project performance.

\section{User Participation Contingencies}

The contingencies refer to the context of system development that facilitates user participation or that inhibits that participation (Cavaye, 1995). Various studies have investigated these factors that affect user participation process in IS projects. These factors have been broadly classified into three domains: Organisational domain, technical systems domain, and users domain (Maail, Kurnia, \& Chang, 2010). Organizational domain includes work arrangements, roles, positions, power, values, norms and cultures. Technical system domain includes the physical means and technical know-how by which information processing tasks are accomplished. The users' domain includes the user attributes influencing the system. A list of these factors is provided in Table $2^{2}$. Additionally, search restricted to the period 2008 - 2015 was carried out in databases: ACM, SpringerLink, Science Direct, and AIS e-library based on keyword combinations (user) AND (participation OR involvement OR engagement) in order to identify further evidences of contingencies.

The findings from these studies describe the various factors that facilitate or hinder user participation in various IS projects. These factors represent the various influences that are associated with user participation in IS projects. Understanding of these factors will assist one to appreciate what are the various enablers of user participation in IS projects, or what are the obstacles hindering such participation. For example, the list presented in Table 2 indicates that resource availability, top management awareness and support, etc. are some of the organizational enablers of user participation in IS projects. Similarly, inappropriate management style, constrained project development time, etc. can be some of the organizational level obstacles impeding user participation.

\footnotetext{
2 The list is based on consolidation of evidences reported in (Maail, Kurnia, \& Chang, 2010)
} 


\begin{tabular}{|c|c|c|}
\hline Domain & Factor & References \\
\hline \multirow{6}{*}{ Organization } & Development time & $\begin{array}{l}\text { (Cavaye, 1995; He \& King, 2008; Tudhope, } \\
\text { Beynon-Davies, \& Mackay, 2000) }\end{array}$ \\
\hline & $\begin{array}{l}\text { Resource availability or } \\
\text { constraints }\end{array}$ & $\begin{array}{l}\text { (Cavaye, 1995; Cooper, 2000; He \& King, 2008; } \\
\text { Tait \& Vessey, 1988) }\end{array}$ \\
\hline & $\begin{array}{l}\text { Top management awareness and } \\
\text { support }\end{array}$ & $\begin{array}{l}\text { (Cavaye, 1995; Sabherwal, Jeyaraj, \& Chowa, } \\
\text { 2006) }\end{array}$ \\
\hline & Management style & (Lu \& Wang, 1997) \\
\hline & Project initiator / champion & (Cavaye, 1995; Nasirin, Winter, \& Coppock, 2005) \\
\hline & $\begin{array}{l}\text { Organizational or Managerial } \\
\text { Culture }\end{array}$ & (Butler \& Fitzgerald, 2001) \\
\hline \multirow{5}{*}{$\begin{array}{l}\text { Technical } \\
\text { System }\end{array}$} & Task attributes & $\begin{array}{l}\text { (Cavaye, 1995; Kim \& Lee, 1986; McKeen \& } \\
\text { Guimaraes, 1997; Nasirin, Winter, \& Coppock, } \\
\text { 2005) }\end{array}$ \\
\hline & System attributes & $\begin{array}{l}\text { (Cavaye, 1995; Hwang \& Thorn, 1999; McKeen, } \\
\text { Guimaraes, \& Wetherbe, 1994; Nasirin, Winter, \& } \\
\text { Coppock, 2005; Tait \& Vessey, 1988) }\end{array}$ \\
\hline & Technology availability & (Cavaye, 1995) \\
\hline & Expected system impact & (Lin \& Shao, 2000; Tait \& Vessey, 1988) \\
\hline & $\begin{array}{l}\text { System development } \\
\text { methodologies }\end{array}$ & (Lin \& Shao, 2000) \\
\hline \multirow{5}{*}{ Users } & Ability to participate & $\begin{array}{l}\text { (Cavaye, 1995; Davidson, 1999; Gallivan \& Keil, } \\
\text { 2003; Hartwick \& Barki, 1994; Hunton \& Price, } \\
\text { 1997) }\end{array}$ \\
\hline & Willingness to participate & $\begin{array}{l}\text { (Cavaye, 1995; Davidson, 1999; Hartwick \& Barki, } \\
\text { 1994) }\end{array}$ \\
\hline & User characteristics and attitudes & $\begin{array}{l}\text { (Cavaye, 1995; livari \& Igbaria, 1997; Nasirin, } \\
\text { Winter, \& Coppock, 2005; Tait \& Vessey, 1988) }\end{array}$ \\
\hline & User communication and training & $\begin{array}{l}\text { ( Nasirin, Winter, \& Coppock, 2005; Sabherwal, } \\
\text { Jeyaraj, \& Chowa, 2006) }\end{array}$ \\
\hline & User experience & (Sabherwal, Jeyaraj, \& Chowa, 2006) \\
\hline
\end{tabular}

\section{Participation Motivation}

Simply put, motivation is the underlying reason for a person's actions ("Motivation", 2017). These "reasons" are different from the factors listed in Table 2 in the sense that these reasons imply the rationale or the logic pertaining to the task in concern whereas the factors represent the influences that contribute to a result. Even though understanding participation motivation has assumed prominence in studies on sports and recreational activities (e.g., Ewert, Gilbertson, Luo, \& Voight, 2013), there are instances of similar studies in IS projects and mostly in the context of
OSS developments (Benbya \& Belbaly, 2010; Mair, Hofmann, Gruber, Hatzinger, Zeileis, \& Hornik, 2014). A number of motivational theories explain how motivation influences choice, persistence, and performance (e.g., Ambrose \& Kulik, 1999). Even though we do not intend to provide an exhaustive review of motivation theories, we want to identify the relevant theories which may be instrumental in explaining user participation in IS project context. Central to these considerations is the focus on theories that can explain autonomous work and task-related motivation. A number of studies have used the self-determination theory (SDT) (Table 3) in order to explain 
participation motivation in OSS projects (e.g., Bitzer, Schrettl, \& Schröder, 2007; Lakhani \& Wolf, 2005; Roberts, Hann, \& Slaughter., 2006; Ke \& Zhang, 2009). Acknowledging the multifaceted and complex nature of motivation, Benya and Belbaly (2010) posits three additional theoretical lenses to explain the motivational contexts specific to OSS, viz. goal- orientation, expectancy, and social exchange (Table 3). Further, the job characteristics theory (JCT) (Table 3) has also been found to be relevant in IS project contexts where the work itself is identified as the main motivator pertaining to the stakeholders concerned (Beecham, Baddoo, Hall, Robinson, \& Sharp, 2008).

\section{Table 3 - Select Motivational Theories}

\begin{tabular}{|l|l|}
\hline Theory & Explanation \\
\hline $\begin{array}{l}\text { Expectancy } \\
\text { (Vroom, 1964) }\end{array}$ & $\begin{array}{l}\text { The theory proposes an individual will behave or act in a certain way } \\
\text { because they are motivated to select a specific behavior over other } \\
\text { behaviors due to what they expect the result of that selected behavior will } \\
\text { be. }\end{array}$ \\
\hline $\begin{array}{l}\text { Goal-orientation } \\
\text { (Nicholls, 1984) }\end{array}$ & $\begin{array}{l}\text { The theory is based on the premise that people are motivated to reach } \\
\text { goals. They will consequently direct their behavior in pursuit of these goals. }\end{array}$ \\
\hline $\begin{array}{l}\text { Job Characteristics } \\
\text { \&eory (JCT) (Hackman }\end{array}$ & $\begin{array}{l}\text { The theory specifies five core job dimensions (i.e. skill variety, task identity, } \\
\text { task significance, autonomy, and feedback) that will lead to critical } \\
\text { psychological states in concerned individuals, and thereby affecting job } \\
\text { outcomes. }\end{array}$ \\
\hline $\begin{array}{l}\text { Self-determination } \\
\text { (SDT) (Deci \& Ryan, } \\
\text { 2002) }\end{array}$ & $\begin{array}{l}\text { The theory differentiates between intrinsically motivated behaviors arising } \\
\text { out of interest and extrinsically motivated behaviors requiring an } \\
\text { instrumentality between the activity and some separable consequences, } \\
\text { such as tangible or verbal rewards. }\end{array}$ \\
\hline $\begin{array}{l}\text { Social Exchange } \\
\text { (Blau, 1964) }\end{array}$ & $\begin{array}{l}\text { The theory proposes that social behavior is the result of an exchange } \\
\text { process between parties. The motivation behind social exchanges is } \\
\text { considered as a process of cost-benefit analyses in which people make } \\
\text { decisions based on their individual satisfaction level within the relationship. }\end{array}$ \\
\hline
\end{tabular}

To summarize, even though user participation in IS projects has received considerable attention from the academic community, the motivation for (business) users' participation has not been systematically examined. By taking a multitheoretical perspective, we further recognize that such participation in IS projects is likely to be driven by heterogeneous motives and that no single theoretical framework can provide a complete explanation. Instead different motivational theories may be better in explaining participation in different project contexts. Operationalization of the user participation motives are expected to offer insights into mechanisms that foster participation of users in IS projects so as to achieve the intended outcome.

\section{Research Methods}

\section{Research Design}

The research design in this study applied a sequential exploratory strategy, i.e. a mixedmethods research design that is characterised by the collection and analysis of qualitative data followed by the collection and analysis of quantitative data (Creswell, 2009). As shown in Figure 1, we first use the focus group interviews, based on which we arrive at the initial measurement items 
characterizing user participation (UP) motives. The focus group was solely used to develop these measurement items in absence of evidences from the literature on user participation which has not directly dealt with addressing the reasons for user participation in IS projects. We subsequently validate these measurement items based on multivariate analysis of data collected through survey to arrive at a dimensional representation of user participation motives.

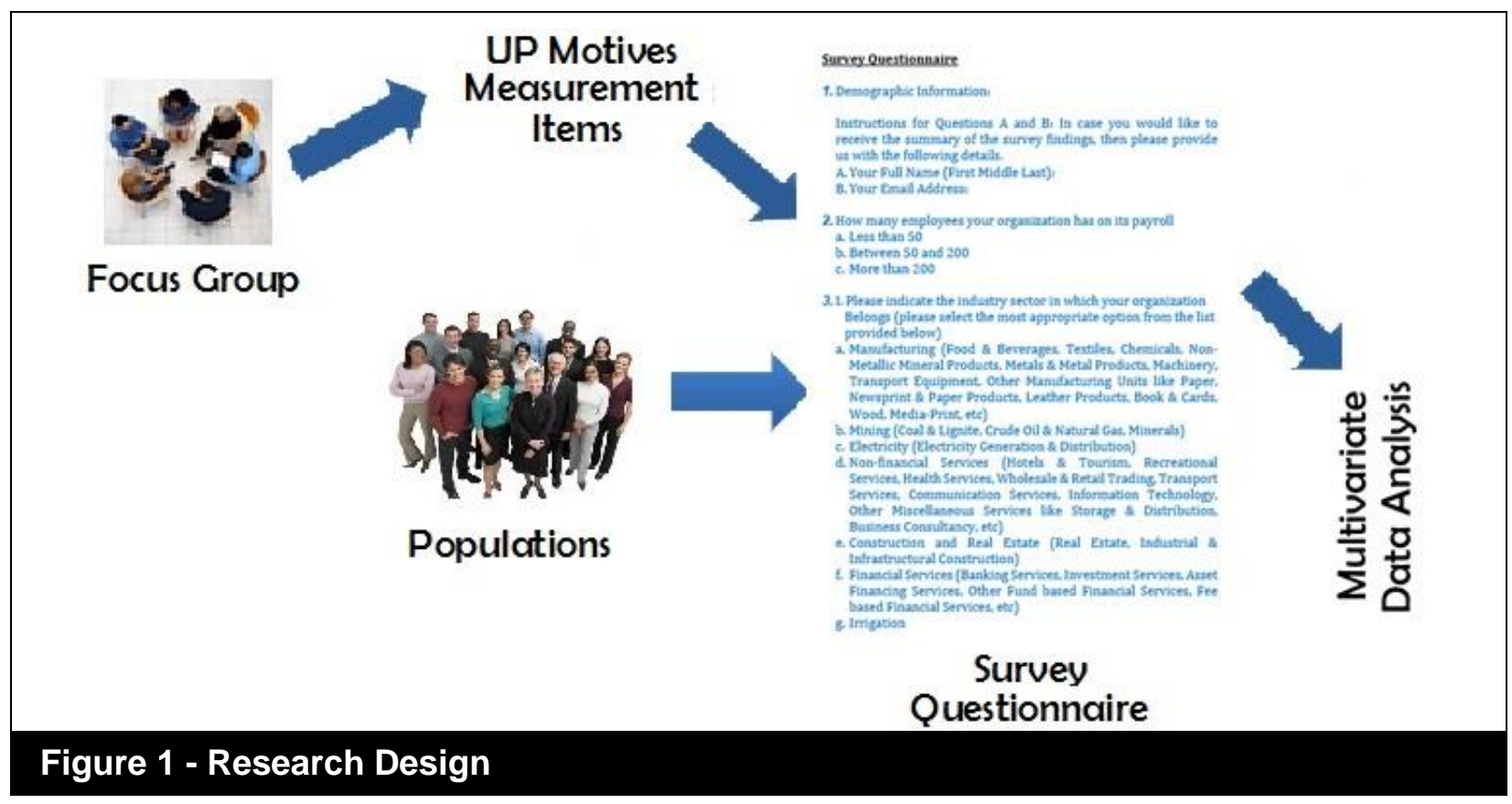

\section{Focus Group Interviews}

We carried out focus group interviews with project managers of five organizations (manufacturing sector: 2, financial services: 1, non-financial services: 2), which have participated as clients to various software development initiatives. Project managers of these organizations were chosen as they are likely to be the key decision makers with regard to the project functionalities from a user's perspective, and these individuals have themselves participated in software development initiatives as a lead user or in equivalent capacities. The objective of the focus group interviews was to gather the participant's preferred notions regarding various facets of their participation as users in software development projects initiated by their respective organizations. This in turn would contribute to the development of measurement items on user participation motives for subsequent validation. The focus group interview was preferred over traditional one-to-one interview as the purpose of this research phase was to arrive at a general consensus among the participants regarding the different facets of user participation.

Five rounds of focus group interviews were conducted in separate organizations, each lasting between one and one-and-half hours, and a total of 18 individuals (three groups with four members in each, and the remaining two groups with three members in each) participated in it. The focus group participants were chosen based on communicating the profile requirements to the human resource personnel of the participating organizations, and then prioritized based on the participants' availability. The demographic information of the focus group participants provided in Table 4 indicates the level of competency of the constituent groups. 


\section{Table 4 - Demographic Information (Focus Group Participants)}

\begin{tabular}{|l|c|l|l|c|}
\hline Designation & Count & Age (year) & Count \\
\hline Systems Analyst & 3 & & $<30$ & 6 \\
\hline Business Analyst & 2 & $30-40$ & 9 \\
\hline Project Manager & 5 & & $>40$ & 3 \\
\hline Junior Manager & 3 & & & \\
\hline Deputy General Manager (Systems) & 1 & & Software Expertise (Year) & Count \\
\hline Consultant & 3 & & $0-5$ & 1 \\
\hline Senior Consultant & 1 & & $6-10$ & 4 \\
\hline & & & $>10$ & 13 \\
\hline
\end{tabular}

An interview guide (not included) was prepared which contained questions on the notion of the user participation, aspects that could be responsible behind the interviewees' participation in the projects as users, and aspects related to managing user participation in projects. The constant comparative method (Glaser \& Strauss, 1967) was used for the analysis of the interview content. The analysis proceeded in three stages. During the first stage (i.e. open coding), the responses were codified, the codes being generated from the data, rather than predetermined. Each code representing a theme or idea with which each part of the data was associated. A spreadsheet template was created by the researcher (i.e. the author himself) with individual columns assigned to these codes in order to facilitate this process. During the second stage (i.e. axial coding), the codes that had common elements were subsequently merged to form categories (Strauss \& Corbin, 1990). Finally, in the third stage (i.e. selective coding), themes were developed that expressed the content of each of the identified groups. Analysis of these themes by the researcher led to the identification of the preliminary set of measurement items characterizing user participation motives which are listed in the Appendix (Part 1). These measurement items were considered for inclusion in the survey design and has been detailed below.

\section{Survey Design and Data Collection}

We developed a survey questionnaire in English using word application in order to validate the measurement items identified above and identify project user's viewpoint regarding their participation in IS development projects. The first page of the survey questionnaire introduced the survey objective and also emphasized that all data would be handled with the strictest confidentiality and that the identity of the respondent could not be inferred. The questionnaire contained three sections. The first section containing seven questions requested demographic details from the respondents. The second section containing 15 questions requested for specific project details, and also contained questions related to respondents' experience and perception regarding participation in a major IS project within the last three years. This section included the measurement items on motives for user participation (24) listed above and project outcome (21) (both listed in the Appendix, Part 1). The final section contained two questions on response precision and comments. All the measurement items were anchored on the 5-point Likert scale, with anchors ranging from 1 (strongly disagree) 
to 5 (strongly agree). Pre-testing of the questionnaire was subsequently carried out with six experts in order to improve content validity and reliability of the survey questionnaire. We discuss in detail the reliability and validity of the survey instrument items in the Section "Reliability and Validation Analysis" later in this document.

The survey was targeted at individuals who have participated as business users in IS project. We did not focus on any specific IS artifact in general, the only requirement being the concerned project is a software development project. We took the help of an external agency in order to access the desired population and complete the survey questionnaire. The data collection process took place between March, 2016 and July,
2016. In total, 350 respondents filled up the survey. While going through the responses, we found a number of responses to be either ambiguous or incomplete. We considered only fully completed questionnaires for further analysis. Hence after filtering out those responses, a total of 183 usable responses, all from India, were finally available to us for subsequent analysis. Table 5 reports on the demographic characteristics. In the table, organization size classification has been made based on the number of employees the concerned user organization has on its payroll. The maturity levels provide an indication of the maturity of the organizations business processes. A description of these maturity levels is included in the Appendix (Part 2).

\section{Table 5 - Demographic Information}

\begin{tabular}{|c|c|c|c|c|c|}
\hline Gender & $\%$ & User Organization Size & $\%$ & User Organization Maturity Level & $\%$ \\
\hline Male & 77.6 & Small ( $<50$ employees) & 44.8 & Level - 1 (minimal efforts at best) & 0.0 \\
\hline Female & 22.4 & $\begin{array}{l}\text { Medium (50-249 } \\
\text { employees) }\end{array}$ & 38.3 & Level -2 (early stage operation) & 27.9 \\
\hline & & Large (>250 employees) & 16.9 & Level -3 (viable processes) & 52.5 \\
\hline Age & $\%$ & Industry Sectors & $\%$ & Level -4 (mature practices) & 17.4 \\
\hline$<31$ & 15.9 & Manufacturing & 30.6 & Level -5 (world class practices) & 2.2 \\
\hline $31-40$ & 37.7 & Financial Services & 20.8 & & \\
\hline $41-50$ & 28.9 & Non-Financial Services & 30.1 & & \\
\hline$>50$ & 17.5 & Others & 18.5 & & \\
\hline
\end{tabular}

\section{Survey Instrument Validation}

The data analysis was carried out using Statistical Package for Social Science (SPSS) 16 software. The survey responses were appropriately coded for the purpose. Given that our study adopted a crosssectional design with all the items being assessed at the same point of time, common method bias (CMB) posed a major threat for the validity. CMB occurs when a significant amount of spurious covariance shared among variables is attributable to the common method used in collecting data (Malhotra, Kim, \& Patil, 2006). In order to control for this bias, we used procedural remedies recommended by Podsakoff, MacKenzie, Lee, \& Podsakoff (2003) such as offering complete anonymity to respondents as well as reducing ambiguity by means of pre-testing. In terms of statistical remedies to control for $\mathrm{CMB}$, we used the Harman's single-factor test 
(Malhotra, Kim, \& Patil, 2006). According to this test, CMB is present if a single factor accounts for the majority of the variance in the variables. Our results demonstrate distinct factor structure with the first factor only accounting for about $25.51 \%$ of variance in variables related to the user participation motives (Table 8). Consequently, having used both procedural and statistical remedies to control for CMB, we posit that $\mathrm{CMB}$ did not significantly affect our results.

Non-response bias generally occurs when some of the target respondents do not participate in the survey and, thus, cause an unreliable representation of the selected sample. Even with a large number of responses and high response rates, strong hypothetical differences in the non-response group can produce misleading conclusions that do not generalize the entire target group and, consequently, limit a study's external validity (King \& He, 2005). Before and during the data collection, we followed the recommendations by Rogelberg \& Stanton (2007) on minimizing non-response: We designed the survey carefully, emphasized the importance of the respondents' participation and our high estimation of the respondents' opinions. After the data collection, we assessed the nonresponse bias by verifying that the responses of early and late respondents did not differ significantly. The idea behind this approach is that late respondents are more likely to resemble non-respondents than early respondents (Armstrong \& Overton, 1977). We defined early respondent group as those who responded within the first half of the survey period, while late respondent group did so within the second half. We used the non-parametric Mann-Whitney test (Mann \& Whitney, 1947) to test for differences between the two groups, with the results demonstrating no significant differences with respect to age, user organization size, and user organization maturity level. Thus, we assume that the study is not affected by a significant nonresponse bias.

\section{Results}

\section{Principal Component Analysis}

At the onset, we examined the following two indicators to determine whether the sample was appropriate for such an analysis. The Kaiser Meyer-Olkin (KMO) measure of sampling adequacy is an index used to examine the appropriateness of factor analysis with values ranging between 0.5 and 1.0 considered appropriate (Leech, Barrett, \& Morgan, 2005). The result of the $\mathrm{KMO}$ measure of sampling adequacy index was 0.598, and the Bartlett's test of sphericity was $2.783 \mathrm{E} 3$ with 276 degrees of freedom which is significant at $\alpha$ : 0.05 . This suggests that the sample and correlation matrix are appropriate for the analysis (Table 6).

\section{Table 6 - KMO and Bartlett's test}

\begin{tabular}{|l|l|}
\hline Tests & Results \\
\hline Kaiser Meyer-Olkin (KMO) measure of sampling adequacy & 0.598 \\
\hline Bartlett's test of sphericity & \multicolumn{2}{|l|}{} \\
\hline Approximation Chi-square & $2.783 \mathrm{E} 3$ \\
\hline Degree of freedom (df) & 276 \\
\hline p-value & 0.000 \\
\hline
\end{tabular}


The Principal Component Analysis (PCA) is a technique that is used to transform a number of possibly correlated variables into a smaller number of variables called principal components that summarize the overall variance. Our objective at this stage was to simply reduce the correlated observed variables to a smaller set of important independent composite variables that retain as much variance as possible. We performed the PCA using promax rotation (oblique) in order to identify the correlation among the measurement items (mentioned above) and arrive at the principal components. Promax rotation was used as it was not known to us if the underlying constructs are uncorrelated. The number of factors to retain was based on a combination of methods (e.g. eigenvalue > 1.0 , scree plot) as well as conceptual clarity, interpretability, and simple structure.

\section{Table 7 - Component Correlation Matrix}

\begin{tabular}{|c|c|c|c|c|c|c|}
\hline Component No. & 1 & 2 & 3 & 4 & 5 & 6 \\
\hline 1 & 1 & 0.242 & 0.293 & -0.141 & 0.035 & -0.134 \\
\hline 2 & 0.242 & 1 & 0.377 & -0.039 & 0.233 & 0.254 \\
\hline 3 & 0.293 & 0.377 & 1 & 0.029 & 0.117 & -0.046 \\
\hline 4 & -0.141 & -0.039 & 0.029 & 1 & 0.098 & -0.085 \\
\hline 5 & 0.035 & 0.233 & 0.117 & 0.098 & 1 & 0.158 \\
\hline 6 & -0.134 & 0.254 & -0.046 & -0.085 & 0.158 & 1 \\
\hline
\end{tabular}

Extraction Method: Principal Component Analysis.

Rotation Method: Promax with Kaiser Normalization.

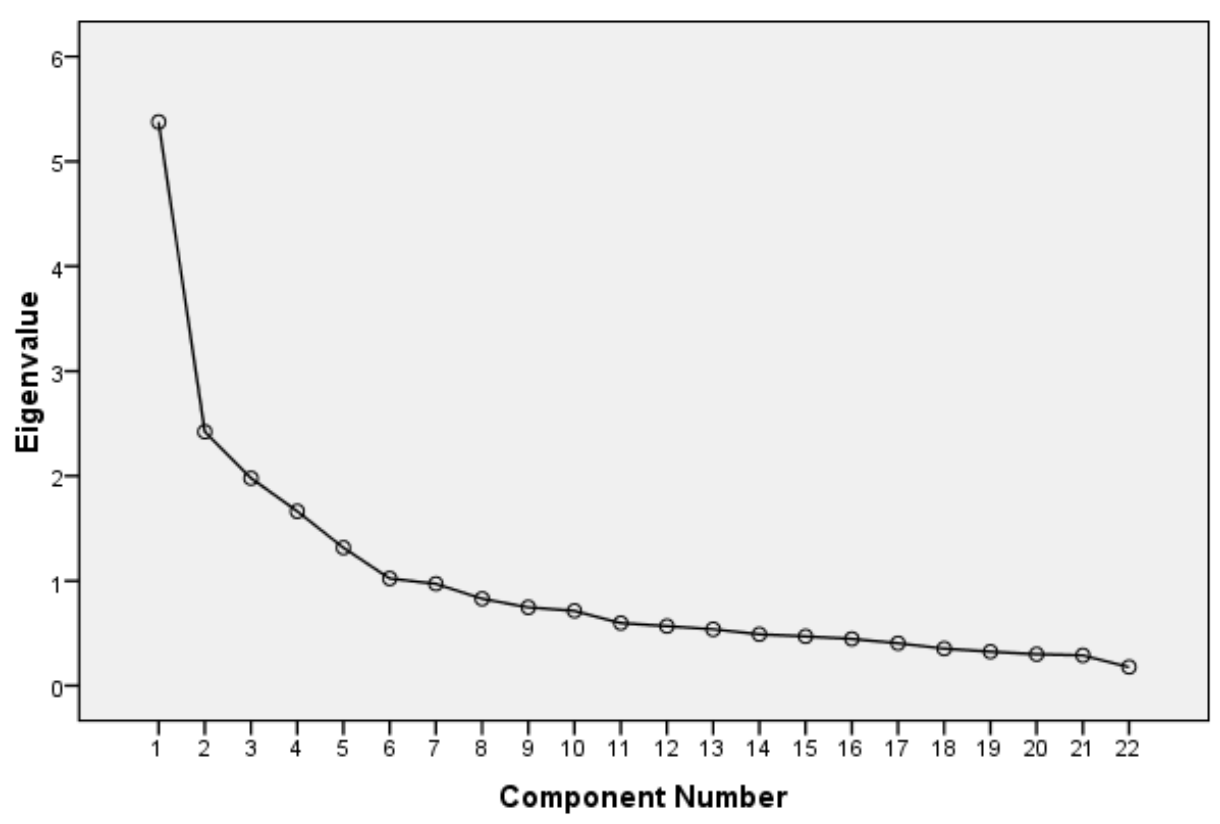

\section{Figure 2 - Scree Plot}


Execution of the PCA in multiple rounds proceeded by checking for any possible outliers in the data based on factor score values larger than $|3.0|$ (Treiblmaier \& Filzmoser, 2010) and if the MSA (Measure of Sampling Adequacy) values reported on the main diagonal of the anti-image correlation matrix was below 0.5 (Field, 2013). The analysis led to a deletion of two items (i.e. Dn and NI). The component correlation matrix was inspected (Table 7) in order to identify the extent of correlation among the factors extracted. The result indicates all but one correlation values to be lower than 0.32 implying that the solution remains nearly orthogonal warranting usage of orthogonal rotation in subsequent rounds (Costello \& Osborne, 2005). The PCA led to an extraction of six factors. Figure 2 presents the scree plot which displays the eigenvalues associated with a factor in descending order along the $\mathrm{Y}$-axis versus the number of factors along the $X$-axis. The point where the slope of the curve is clearly leveling off (the "elbow") indicates the number of factors that should be generated by the analysis. As Figure 2 demonstrates, the scree plot of eigenvalues tends to flatten out between 6 and 7 factors.

\section{Exploratory Factor Analysis}

Exploratory Factor Analysis (EFA) is a technique to determine the nature of the possible underlying structure of latent factors which are responsible for the shared (common) variance in a set of observed variables / items. Our objective at this stage was to explore the underlying factor structure that maximally explain the covariance among the reduced set of observed indicators obtained from PCA. We used the principal axis factoring extraction method with varimax rotation as the findings from PCA suggested that the components are mostly uncorrelated (Table 7 ), and the factor extraction criteria was set at six following the PCA results.

The communality score of the items was inspected to find out if the value was atleast 0.4 (Costello \& Osborne, 2005). We expected the items to preferably load greater than 0.32 on the relevant factor and less than 0.32 on all other factors (Tabachnick \& Fidell, 2001). We deleted items having less than 0.15 absolute differences between the primary loading and cross loading on any other (Floyd \& Widaman, 1995). The analysis is multiple rounds led to a deletion of five items at this stage (USO, IA, FA, GII, CJ), and prompted a revision of the factor extraction criteria from six to five as it violated the requirement of minimum two items to distinctly define a factor i.e. Factor 6 (Henson \& Roberts, 2006).

The combined analysis resulted in pruning down the initial list of 24 items on user participation motives to 17 items which accounted for about $50.25 \%$ variation in the data. The factor pattern coefficients, eigenvalue scores, percentage of variance accounted by each factor, communalities (h2) of the measured variables, and descriptions of the constituent items are presented in Table 8. In the table, coefficients greater than |.32| are italicized for the factor under which the corresponding item is retained. 
Table 8 - User Participation Motives Items - Rotated Factor Pattern Matrix, Communalities, Factor Eigenvalue Scores and \% Variances Explained

\begin{tabular}{|c|c|c|c|c|c|c|c|c|}
\hline \multirow{2}{*}{ ID } & \multirow{2}{*}{ Item Name } & \multicolumn{5}{|c|}{ Factors $^{a}$} & \multirow{2}{*}{$h^{2}$} & \multirow{2}{*}{ Item Description } \\
\hline & & $\begin{array}{c}\text { Factor } \\
1\end{array}$ & $\begin{array}{l}\text { Factor } \\
2\end{array}$ & $\begin{array}{c}\text { Factor } \\
3\end{array}$ & $\begin{array}{l}\text { Factor } \\
4\end{array}$ & $\begin{array}{l}\text { Factor } \\
5\end{array}$ & & \\
\hline PSC & $\begin{array}{l}\text { Part of Steering } \\
\text { Committee }\end{array}$ & 0.623 & 0.114 & 0.204 & 0.067 & -0.050 & 0.449 & $\begin{array}{l}\text { The association of the user with the concerned } \\
\text { project is governed by his/her commitments as a } \\
\text { part of the project steering committee. }\end{array}$ \\
\hline$A D$ & Authority Directive & 0.623 & 0.134 & 0.122 & 0.281 & 0.173 & 0.529 & $\begin{array}{l}\text { The association of the user with the project is } \\
\text { governed by the authoritative directives passed } \\
\text { on to the user. }\end{array}$ \\
\hline TUM & Team User Mediation & 0.594 & 0.235 & 0.178 & 0.104 & -0.043 & 0.453 & $\begin{array}{l}\text { The association of the user with the project is to } \\
\text { mediate between the concerned parties during } \\
\text { project execution. }\end{array}$ \\
\hline $\mathrm{RF}$ & $\begin{array}{l}\text { Requirement } \\
\text { Finalization }\end{array}$ & 0.591 & 0.281 & 0.206 & 0.208 & -0.127 & 0.531 & $\begin{array}{l}\text { The association of the user with the project is to } \\
\text { assist in requirement selection tasks. }\end{array}$ \\
\hline PDT & $\begin{array}{l}\text { Part of Development } \\
\text { Team }\end{array}$ & 0.391 & 0.562 & 0.226 & 0.093 & 0.052 & 0.587 & $\begin{array}{l}\text { The association of the user is implied as the user } \\
\text { is part of the software development team. }\end{array}$ \\
\hline GSI & $\begin{array}{l}\text { Generate Software } \\
\text { Inputs }\end{array}$ & 0.077 & 0.764 & 0.203 & 0.047 & -0.022 & 0.633 & $\begin{array}{l}\text { The reason behind user participation in the } \\
\text { concerned project is to generate technical inputs } \\
\text { for the software. }\end{array}$ \\
\hline OD & $\begin{array}{l}\text { Overseeing } \\
\text { Development }\end{array}$ & 0.195 & 0.675 & 0.160 & 0.037 & 0.131 & 0.537 & $\begin{array}{l}\text { The reason behind user participation in the } \\
\text { concerned project is to oversee the technicalities } \\
\text { of the project. }\end{array}$ \\
\hline ATA & $\begin{array}{l}\text { Acceptance Test } \\
\text { Assistance }\end{array}$ & 0.219 & 0.413 & 0.098 & 0.103 & 0.317 & 0.439 & $\begin{array}{l}\text { The reason behind user participation in the } \\
\text { concerned project is to assist in project } \\
\text { acceptance testing. }\end{array}$ \\
\hline ITU & $\begin{array}{l}\text { Introduce Team to } \\
\text { Users }\end{array}$ & 0.151 & 0.149 & 0.649 & 0.133 & -0.022 & 0.485 & $\begin{array}{l}\text { The reason behind user participation in the } \\
\text { concerned project is to introduce co-users to the } \\
\text { project development team. }\end{array}$ \\
\hline TU & Trained Users & 0.145 & 0.158 & 0.601 & -0.284 & 0.106 & 0.499 & $\begin{array}{l}\text { The reason behind user participation in the } \\
\text { concerned project is to train other users in the } \\
\text { software. }\end{array}$ \\
\hline
\end{tabular}


Thakurta: Identifying the Motives for User Participation in Information Sys

Identifying the Motives for User Participation in Information System Projects / Thakurta

\begin{tabular}{|c|c|c|c|c|c|c|c|c|}
\hline $\mathrm{FF}$ & Feedback on Features & 0.194 & 0.275 & 0.560 & -0.191 & 0.216 & 0.511 & $\begin{array}{l}\text { The reason behind user participation in the } \\
\text { concerned project is to communicate project } \\
\text { feedback to the other users. }\end{array}$ \\
\hline TCD & Test Case Design & 0.228 & 0.411 & 0.562 & 0.044 & -0.140 & 0.456 & $\begin{array}{l}\text { The reason behind user participation in the } \\
\text { concerned project is to assist co-users in } \\
\text { developing test cases. }\end{array}$ \\
\hline OS & Operate Software & 0.197 & 0.046 & -0.060 & 0.670 & -0.130 & 0.510 & $\begin{array}{l}\text { The user participation in the concerned project is } \\
\text { driven by his/her interest in operating the } \\
\text { software. }\end{array}$ \\
\hline OrC & Organizational Changes & 0.194 & 0.160 & -0.082 & 0.628 & 0.121 & 0.479 & $\begin{array}{l}\text { The user participation in the concerned project is } \\
\text { driven by his/her interest to facilitate changes in } \\
\text { the organization. }\end{array}$ \\
\hline SPR & $\begin{array}{l}\text { Software Personally } \\
\text { Relevant }\end{array}$ & -0.097 & 0.133 & 0.066 & -0.020 & 0.749 & 0.592 & $\begin{array}{l}\text { The user participation in the concerned project is } \\
\text { attributed to the personal relevance of the project } \\
\text { outcome to the participating user. }\end{array}$ \\
\hline $\mathrm{CO}$ & Critical to Organization & -0.058 & -0.084 & 0.065 & 0.457 & 0.619 & 0.468 & $\begin{array}{l}\text { The user participation in the concerned project is } \\
\text { attributed to the project's perceived criticality to } \\
\text { the participant user organization. }\end{array}$ \\
\hline DwT & Discussions with Team & 0.477 & 0.026 & -0.059 & -0.139 & 0.632 & 0.483 & $\begin{array}{l}\text { The user participation in the concerned project is } \\
\text { attributed to the relevance of issues pertaining to } \\
\text { the software under development, necessitating } \\
\text { discussion with the project team. }\end{array}$ \\
\hline \multicolumn{2}{|c|}{ Eigenvalue scores } & 4.827 & 2.061 & 1.741 & 1.302 & 1.074 & & \\
\hline \multicolumn{2}{|c|}{ \% Variance Explained } & 25.509 & 9.178 & 7.409 & 4.805 & 3.345 & & \\
\hline
\end{tabular}




\section{User Participation Motives}

Based on Table 8 results, five factors can be identified which we discuss now. The first factor comprised of five items i.e. PSC, $A D, T U M, R F$, and PDT, and explained about $25.51 \%$ of the total variance. These items based on their description (Table 8) mostly relate to the nature of association of the respondent with the project organization or the development team. The factor is hence named as Nature_Of_Association.

The second factor contained three items i.e. GSI, OD, and ATA, and explained about $9.18 \%$ of the total variance. These three items reason respondent's participation in the project to provide technical assistance during project development, e.g. generating inputs for the software, facilitating project acceptance testing, etc. Hence the factor is named as Techno_Centric_Activity.

The third factor contained four items i.e. ITU, TU, FF, and TCD, and explained about $7.41 \%$ of the total variance. The items constituting this factor represent activities that are directed at project users' group. The items imply some kind of assistance that is provided to these users by the representative(s) of the user organization after their participation in the project. The factor is hence named as User_ Centric_Activity.

The fourth factor contained two items i.e. OS, and OrC, and explained about $4.81 \%$ of the total variance. Both these items indicate the intrinsic interest that may serve as reasons behind user's participation in the project. The factor is hence named as User_Interest.

Finally, factor five contained three items, i.e. SPR, CO, and DwT, and explained about $3.35 \%$ of the total variance. These three items provide a sense of importance of the concerned project, thereby necessitating user participation. This factor is hence named Project_Importance.

\section{Reliability and Validation Analysis}

Reliability refers to the extent to which the intended operationalization of user participation motives remains consistent over time, and was assessed based on the following: test-retest reliability, and assessment of the strength of indicators to construct path coefficients.

Test-retest reliability is estimated by administering the same instrument to the same sample on two different occasions on the assumption there will be no substantial change in the construct under study between the two sampling time periods. Test-retest reliability of the instrument was undertaken by administrating the questionnaire after a gap of eight weeks to 15 respondents who had responded during the first month of data collection phase (i.e. March 2016). The results of the analysis (not shown here) based on Wilcoxon NonParametric Statistical Test did not show any significant differences between the responses at the two time periods.

An assessment of the strength of indicators to construct path coefficients provides a measure of the indicator reliability of the associated constructs. The estimation of this reliability was carried out in SPSS by saving the latent variables scores (standardized) corresponding to the factors extracted. The ordinary least square (OLS) regressions were then performed with each factor as the dependent variable and the set of items constituting the factor (ref. Table 8) as the independent variables. The t-values of the item weights were found to be significant ( $\alpha$ : 0.05) (Table 9$)$ demonstrating indicator reliability. 


\begin{tabular}{|c|c|c|c|c|c|}
\hline Factor Name & Item ID & Item Name & $\begin{array}{l}\text { Item } \\
\text { Weight }\end{array}$ & $\mathrm{t}$-values & $p$-value \\
\hline \multirow{5}{*}{ 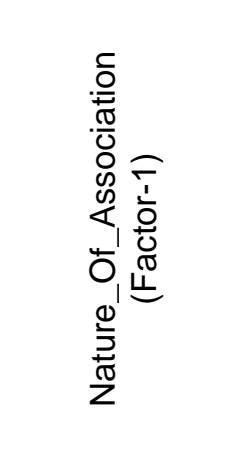 } & PSC & Part of Steering Committee & 0.304 & 8.991 & $p<.0 .05$ \\
\hline & $A D$ & Authority Directive & 0.317 & 9.529 & $p<.0 .05$ \\
\hline & TUM & Team User Mediation & 0.321 & 9.557 & $p<.0 .05$ \\
\hline & $\mathrm{RF}$ & Requirement Finalization & 0.357 & 1.049 & $\mathrm{p}<.0 .05$ \\
\hline & PDT & Part of Development Team & 0.620 & 2.225 & $\mathrm{p}<.0 .05$ \\
\hline \multirow{3}{*}{ 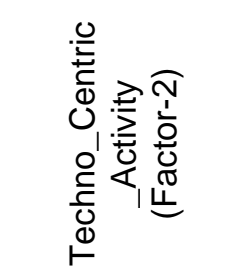 } & GSI & Generate Software Inputs & 0.064 & 2.285 & $p<.0 .05$ \\
\hline & OD & Overseeing Development & 0.194 & 7.005 & $\mathrm{p}<.0 .05$ \\
\hline & ATA & Acceptance Test Assistance & 0.614 & 2.837 & $\mathrm{p}<.0 .05$ \\
\hline \multirow{4}{*}{ 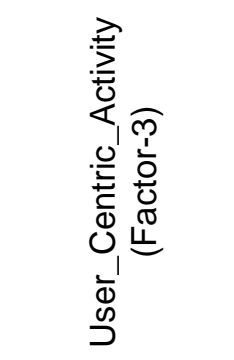 } & ITU & Introduce Team to Users & 0.524 & 1.417 & $p<.0 .05$ \\
\hline & TU & Trained Users & 0.863 & 3.545 & $\mathrm{p}<.0 .05$ \\
\hline & $\mathrm{FF}$ & Feedback on Features & -0.112 & -3.392 & $\mathrm{p}<.0 .05$ \\
\hline & TCD & Test Case Design & 0.344 & 1.385 & $p<.0 .05$ \\
\hline \multirow{2}{*}{ 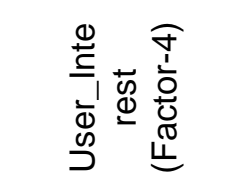 } & os & Operate Software & 0.570 & 6.420 & $p<.0 .05$ \\
\hline & OrC & Organizational Changes & 0.598 & 6.735 & $\mathrm{p}<.0 .05$ \\
\hline \multirow{3}{*}{ 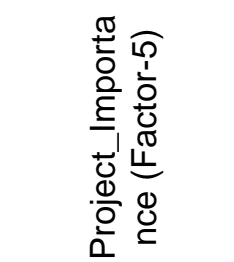 } & SPR & Software Personally Relevant & 0.266 & 1.043 & $p<.0 .05$ \\
\hline & $\mathrm{CO}$ & Critical to Organization & 0.869 & 3.411 & $\mathrm{p}<.0 .05$ \\
\hline & DwT & Discussions with Team & 0.365 & 3.219 & $\mathrm{p}<.0 .05$ \\
\hline
\end{tabular}

The validity of a measure refers to the extent to which it measures what is intended to be measured. Given that our study employs the principal components analysis (PCA), and the exploratory factor analysis (EFA), the following types of validity were considered: content validity, and construct validity.

A measure can be said to possess content validity if there is a general agreement among the subjects and researchers that constituent items cover all aspects of the 
construct being measured (Nunnally \& Bernstein, 1978). We relied on expert reviews in order to assess the content validity. The set of items on user participation motives were shared with six experts $^{3}$ known to the researcher to assess the relevance of the items as motives of user participation. The results based on a 5point Likert-type (1: not relevant, 5: very relevant) indicated that in overall $58.3 \%$ of the cases, an item has been rated as 4 (64 occurrences), or 5 (20 occurrences) with the weighted average rating as 4.23. Further, none of the items were judged by any of the experts to be totally irrelevant (i.e., a rating of 1$)$. Hence we retained all the items and further modified some of the items which were rated as two by the experts. Pretest subjects assessing the survey questionnaire also indicated that the content of each factor was well represented by the constructs employed.

Construct validity is concerned with the extent to which the theoretical essence of the measure is captured. In this case, construct validity was evaluated by examining convergent validity which refers to the extent to which measures within a factor are correlated. A method for determining convergent validity during EFA is to analyse the factor loadings. The rotated factor pattern matrix presented in Table 8 clearly indicates that five components are loaded. The results satisfy the criteria of convergent validity (Eigenvalues of 1, item loadings (rounded) of 0.4 and above on posted constructs) (Straub, Boudreau, \& Gefen, 2004).

\section{Discussion}

\section{Observation on the Results}

The results of the exploratory factor analysis demonstrate a five factor structure

\footnotetext{
${ }^{3}$ Two from academia having interests in software engineering and project management. Rest four were IT practitioners with over 20 years of experience.
}

comprising of Nature_Of_Association, Techno_Centric_Activity, User_Centric Activity, User_Interest, and Project_ Importance. These motives are an indication of the users' own needs of participating in the concerned IS projects and not somebody else viewpoints. These different dimensions characterising the motives offer insights into the considerations associated with user's participation in IS projects. For example, the dimension Project Importance indicates project related aspects that the users may perceive to be important.

During analysis, item CJ was deleted during the analysis stage as its loading on the factor could not be conceptually interpreted. This item is interpreted as 'Critical to Job', and measured in terms of the respondent's agreement to the following statement: I participated as the project is critical with respect to my job/career needs. The way in which the item was phrased implied some kind of importance of the concerned project, which necessitated user participation (i.e. the project is important in terms of career needs of the concerned user). The item however is found to load acceptably along with the items ITU (Introduce Team to Users), FF (Feedback on Features), TU (Trained Users), and TCD (Test Case Design). These four items are interpreted as user centric activities and are in no way related to the item $\mathrm{CJ}$, the manner in which it was conceptualized.

In Table 8, the items PDT (Part of Development Team), TCD (Test Case Design), CO (Critical to Organization), and DwT (Discussions with Team) can be seen to load acceptably on multiple factors. Item PDT loads adequately on Factor-1 and Factor-2, with the loading on Factor-2 being of higher value. PDT is measured in terms of the respondent's agreement to the following statement: I participated as I was already a part of the project team which developed the software. The statement emphasise more on the nature of association (i.e. the user is associated with the project team itself), without indication on 
the type of the activity that the user may be required to carry out during its participation in the project. Based on this justification, the item is retained against Factor-1 (interpreted as Nature_Of_Association).

Item TCD is found to load adequately on Factor-2 and Factor-3 with the loading on Factor-3 being of higher value. TCD is measured in terms of the respondent's agreement to the following statement: I participated in order to assist other users in my organization in designing test cases. The statement refers to people centric activities (i.e. assisting other users) carried out by the concerned user. There is no reference of any technicalities of the activity from the above mentioned statement. Hence the item is retained against Factor-3 (interpreted as User_Centric_Activity).

Item $\mathrm{CO}$ is found to load adequately on Factor-4 and Factor-5 with the loading on Factor- 5 being of higher value. The item is measured in terms of the respondent's agreement to the following statement: I participated as the project is critical to the needs of my organization. The statement provides some indication of the importance of the project (i.e. the project is important from the organizational perspective). The item is hence retained against Factor-5 (interpreted as Project_Importance).

Lastly, item DwT is found to load adequately on Factor-1 and Factor-5 with the loading on Factor- 5 being of higher value. DwT is measured in terms of the respondent's agreement to the following statement: I participated as and when the development team included me in their discussion on relevant issues related to the project under consideration. We have interpreted the same as demonstration of pro-activeness by the development team in engaging the concerned user. This seems likely if the project team perceives the project to be important given the underlying objectives. The item thus signifies project importance to the development team, and hence retained against Factor-5.
The literature highlights a number of factors influencing user participation in IS projects, a summary of which we have presented in Table 2. These factors represent the enablers or the obstacles to user participation in IS projects. Hence even if there are pertinent reasons for users to participate, the Table 2 factors may eventually govern the extent of such participation or the nature of such participation during project development. For example, the dimension Techno_Centric_Activity reasons respondent's participation in the project to provide technical assistance in the development of the software under consideration. Such participation might not be actually possible if there is no top management support encouraging the user's participation in the concerned project. Hence the presence/absence of the factor "top management awareness and support" (Table 2) acts as an enabler/obstacle towards realizing the user's intended behaviour (i.e. participation in the project). Hence our study results also contribute to the understanding on how the various user participation factors as acknowledged in the prior literature are actually different from the user participation motives which we present in this study.

\section{Theoretical and Practical Implications}

Our study reveals a characterization of the user participation motives in five dimensions which extends the existing contributions in the domain. At the onset, we identified some of the dominant theoretical lenses relevant to the context of stakeholder participation in IS projects. Our conceptualization of user participation motives to a large extent confirms to the theoretical basis.

The factor Nature_Of_Association is an indicator of the essential task characteristics depicting the project environment. It is possible that the appreciation of inherent characteristics of the tasks results in a positive impact on the psychological states experienced by the user in concern. Thus, 
as posited by the job characteristics theory (JCT) (Hackman \& Oldham, 1976, 1980), a favourable disposition of the same is expected to result in user participation in forms desired.

Techno_Centric_Activity attribute users' participation in IS projects to specific objectives that the users may want to fulfil like, for example, providing technical assistance to those concerned. This can be explained by the goal orientation theory which have recognized two types of goals: Learning (increasing competence and acquisition of new skills) and Performance (focusing on demonstration and verification of ability by seeking favourable evaluations of individual competence) (Nicholls, 1984). Performance orientation suggests that the users may engage with the project team to demonstrate their ability to others and establish the adequacy of their ability.

User_Interest as conceptualized concur with the intrinsic interest of the users to participate in the concerned project. The motive in this case can be explained by the self-determination theory (SDT) (Deci \& Ryan, 2002). SDT is concerned with supporting our natural or intrinsic tendencies to behave in a desired manner. User interest is a manifestation of the of motivation to get associated with the project team and serve the intended causes.

The conceptualization of User_Centric_Activity accounts for the various assistances provided to users by the representative(s) of the user organization after their participation in the project. This is a kind of co-operative behaviour posited by the social exchange theory (Blau, 1964) where the user representative engages with other co-users either as a gesture of goodwill or to fulfil an obligation out of some previous exchanges.

Project_Importance aggregates the relevance of the project and its issues. In this case the perceived importance of the tasks serves as a motive being user participation and is also aligned with the job characteristics theory (JCT) (Hackman \&
Oldham, 1976, 1980). An acknowledgement of the IS project and issue relevance (i.e. task significance) by the users creates a favourable disposition through intermediate stages resulting in user participation.

These explanations substantiate that motivational processes governing user participation in IS projects do not differ completely from motivational processes in other social communities and teams and can be explained within existing social psychological theories. Even though the results lend support to the multi-dimensional facet of user participation motive, we do not find any evidences confirming support to the relevance of expectancy theory in our studied context. This indicate the possibilities of existence of additional motives to be confirmed in follow-up studies.

Our study has important implications for IS practitioners. The study provides practitioners with additional insights on the different motives for user participation in IS projects. The interpretation of the identified dimensions (excluding Project_Importance which is implicit) can be meaningful to a practitioner in the following way:

- Nature_Of_Association: This provides an understanding of some of the essential considerations prompting participation of the users in the concerned project.

- Techno_Centric_Activity and User_Centric_Activity: Both of these indicate some of the necessary tasks which the participating user is required to do.

- User_Interest: This provides a cue on the motivational basis of the users guiding their participation in the concerned project.

The user participation motives hence can serve as specific handles project managers may use in order to manage user participation in their projects. For example, Project Importance may be showcased in order to ensure user participation at a relatively early stage in the project. 
Additionally, even though we have carried out our study in the context of (business) user participation in IS projects, we believe that some of these results may also be useful to practicing managers in other contexts where engagement of user is key to the success of the endeavour.

\section{Conclusion, Limitations and Future Studies}

What are the different motives for user participation in IS project? In this study, we use multivariate data analysis techniques in order to arrive at initial characterization of the user participation motives. Based on the results of the exploratory factor analysis we are able to propose a five factor structure characterizing the user participation motives. We provide our arguments on how these motives are actually different from the user participation factors which have been studied in depth in the existing literature, and discuss some of the reliability and validity issues of the proposed measures.

Some limitations of the study warrant comment. We had to limit the size of the questionnaire so as to increase the response rate, and this has implications on the composition of the participating constructs. It is possible that we have missed out items that should have been part of one or more dimensions characterizing user participation motives. Further, given that we have relied on an external agency for data collection, we have failed to report the response rate as the same was not communicated to us. The reliance on external agency also raises concerns related to selection bias in our sample. We also expect recollection errors from survey respondent's perspective. Additionally, given the fact that the data collection has been carried out entirely in India, the extension of the study results in other geographic segments needs to account for culture and other factors that might impact the research setting. The absolute value of the sample size that we could achieve is another possible limitation of the study. Although there is no set standard, research into the practices associated with EFA recommends a sample size of 250 as the minimum desirable (Cattell, 1978). Our sample size of 183 fails to meet this specification. We however adhere to the participant-to-item ratio of 5:1 given that our initial list of user participation motives consists of 24 items (Conway \& Huffcutt, 2003). Hence the factor structure derived from the study can be considered to be sufficiently stable and valid for the underlying population. We also exercise caution in interpreting the factor analysis results. The correlations that form the basis of factor analysis demonstrate relationships without any indication of causalities. Establishment of arguments related to the nature of these constructs (i.e. formative or reflexive) can only be established with further analysis (Cenfetelli \& Bassellier, 2009; Petter, Straub, \& Rai, 2007).

The immediate extension of the work will seek to establish the nature of these constructs (i.e. formative or reflexive) obtained from EFA and validate the factor structure using confirmatory factor analysis to define the nature and composition of the different user participation motives. Additional research may also address the limitations and additional inquiry possibilities identified above. Apart from that, research endeavours may also focus on how these user participation motives contribute to the variations in the level of participation of users and influence IS project success. Future research may also investigate the phenomena of interest in other geographic contexts. Furthermore, a comparative study may be carried out in order to investigate the differences, if any, in the conceptualization of user participation motives across geographies, and the possible reasons behind the same. We hope that this research note, apart from extending the existing body of knowledge, also offers insights for designing project 
management strategies that ensures successful endeavors in future.

\section{References}

Abelein, U., \& Paech, B. (2013). Understanding the influence of user participation and involvement on system success - a systematic mapping study. Empirical Software Engineering, 20(1), 28-81.

Ambrose, M. L., \& Kulik, C. T. (1999). Old friends, new faces: Motivation research in the 1990s. Journal of management, 25(3), 231-292.

Armstrong, J. S., \& Overton, T. S. (1977). Estimating nonresponse bias in mail surveys. Journal of Marketing Research (JMR), 14(3), 396-402.

Babcock, P., \& Gove, P. B. (1993). Webster's Third New International Dictionary of the English Language, Unabridged: Since 1847 the Ultimate Word Authority for Schools, Libraries, Courts, Homes, and Offices. Springfield, MA Merriam-Webster.

Bachore, Z., \& Zhou, L. (2009). A critical review of the role of user participation in IS success. AMCIS 2009 Proceedings, 659.

Bakalova, Z., \& Daneva, M. (2011). A comparative case study on clients participation in a'traditional'and in an Agile software company. Paper presented at the Proceedings of the 12th International Conference on Product Focused Software Development and Process Improvement.

Bano, M., \& Zowghi, D. (2015). A systematic review on the relationship between user involvement and system success. Information and Software Technology, 58, 148-169.
Barki, H., \& Hartwick, J. (1989). Rethinking the concept of user involvement. MIS Quarterly, 13(1), 53-63.

Barki, H., \& Hartwick, J. (1991). User participation and user involvement in information system development. Paper presented at the Proceedings of the 24th annual Hawaii International conference on system sciences, Hawaii, USA.

Barki, H., \& Hartwick, J. (1994). Measuring user participation, user involvement, and user attitude. MIS Quarterly, 18(1), 59-82.

Beecham, S., Baddoo, N., Hall, T., Robinson, H. \& Sharp, H. (2008). Motivation in Software Engineering: A systematic literature review. Information and Software Technology, 50(9), 860-878.

Benbya, H., \& Belbaly, N. (2010). Understanding developers' motives in open source projects: a multitheoretical framework. Communications of the Association for Information Systems, 27(1), 589-611.

Bitzer, J., Schrettl, W. \& Schröder, P. J. (2007). Intrinsic motivation in open source software development. Journal of Comparative Economics, 35(1), 160-169.

Bjerknes, G., \& Bratteteig, T. (1995). User participation and democracy: A discussion of Scandinavian research on system development. Scandinavian Journal of information systems, 7(1), 1.

Blau, P. M. (1964). Exchange and power in social life. Ney York, NY: Transaction Publishers.

Brodbeck, F. C. (2001). Communication and performance in software development projects. European Journal of Work \& Organizational Psychology, 10(1), 7394. 
Butler, T., \& Fitzgerald, B. (2001). The relationship between user participation and the management of change surrounding the development of information systems: a European perspective. Journal of End User Computing, 13(1), 1-20.

Cattell, R. B. (1978). The scientific use of factor analysis in behavioral and life sciences. New York: Plenum Press.

Cavaye, A. L. M. (1995). User participation in system development revisited. Information \& Management, 28(5), 311-323.

Cenfetelli, R. T., \& Bassellier, G. (2009). Interpretation of Formative Measurement in Information Systems Research. MIS Quarterly, 33(4), 689707.

Cherry, C., \& Macredie, R. D. (1999). The importance of context in information system design: an assessment of participatory design. Requirements Engineering, 4(2), 103-114.

Clement, A. (1994). Computing at work: empowering action by low-level users. Communication of the ACM, 37(1), 52-63.

Conway, J. M., \& Huffcutt, A. I. (2003). A review and evaluation of exploratory factor analysis practices in organizational research. Organizational Research Methods, 6(2), 147-168.

Cooper, R. B. (2000). Information technology development creativity: A case study of attempted radical change. MIS Quarterly, 24(2), 245276.

Costello, A. B., \& Osborne, J. W. (2005). Best practices in exploratory factor analysis: four recommendations for getting the most from your analysis. Practical Assessment, Research \& Evaluation, 10(7), 1-9.
Creswell, J. W. (2009). Research design: Qualitative, quantitative, and mixed methods approaches (3rd Edition ed.). London: Sage publications.

Davidson, E. J. (1999). Joint application design (JAD) in practice. Journal of Systems and Software, 45(3), 215223.

Deci, E. L., \& Ryan, R. M. (2002). Handbook of Self-Determination Research. In. Rochester, NY: University of Rochester Press.

Doll, W. J., \& Torkzadeh, G. (1989). A discrepancy model of end-user computing involvement. Management science, 35(10), 1151-1171.

Ewert, A., Gilbertson, K., Luo, Y. C., \& Voight, A. (2013). Beyond" because it's there": Motivations for pursuing adventure recreational activities. Journal of leisure research, 45(1), 91.

Field, A. (2013). Discovering statistics using IBM SPSS statistics. London: Sage Publications.

Floyd, F. J., \& Widaman, K. F. (1995). Factor analysis in the development and refinement of clinical assessment instruments. assessment, 7(3), 286.

Gallivan, M. J., \& Keil, M. (2003). The userdeveloper communication process: a critical case study. Information Systems Journal, 13(1), 37-68.

Glaser, B., \& Strauss, A. (1967). The discovery grounded theory: strategies for qualitative inquiry. Chicago, IL: Aldine Publishing Co.

Hackman, J. R. \& Oldham, G. R. (1976). Motivation through the design of work: Test of a theory. Organizational behavior and human performance, 16 (2), 250-279.

Hackman, J. R. \& Oldham, G. R (1980). Work redesign. Reading, MA: Addison-Wesley. 
Harris, M. A., \& Weistroffer, H. R. (2009). A new look at the relationship between user involvement in systems development and system success. Communications of the Association for Information Systems, 24(1), 42.

Hartwick, J., \& Barki, H. (1994). Explaining the role of user participation in information system use. Management science, 40(4), 440-465.

He, J., \& King, W. R. (2008). The role of user participation in information systems development: implications from a meta-analysis. Journal of Management Information Systems, 25(1), 301-331.

Heinbokel, T., Sonnentag, S., Frese, M., Stolte, W. \& Brodbeck, F. C. (1996). Don't underestimate the problems of user centredness in software development projectsthere are many! Behaviour \& information technology, 15(4), 226-236.

Henson, R. K., \& Roberts, J. K. (2006). Use of exploratory factor analysis in published research common errors and some comment on improved practice. Educational and Psychological measurement, 66(3), 393-416.

Hirschheim, R. A. (1983). Assessing participative systems design: some conclusions from an exploratory study. Information \& Management, 6(6), 317327.

Hope, K. L., \& Amdahl, E. (2011). Configuring designers? Using one agile project management methodology to achieve user participation. New Technology, Work and Employment, 26(1), 54-67.

Howcroft, D., \& Wilson, M. (2003). Participation:'bounded freedom' or hidden constraints on user involvement. New Technology, Work and Employment, 18(1), 2-19.
Hunton, J. E., \& Price, K. H. (1997). Effects of the user participation process and task meaningfulness on key information system outcomes. Management science, 43(6), 797-812.

Hwang, M. I., \& Thorn, R. G. (1999). The effect of user engagement on system success: a meta-analytical integration of research findings. Information \& Management, 35(4), 229-236.

livari, J., \& Igbaria, M. (1997). Determinants of user participation: a Finnish survey. Behaviour \& information technology, 16(2), 111-121.

livari, J., \& livari, N. (2011). Varieties of user-centredness: an analysis of four systems development methods. Information Systems Journal, 21(2), 125-153.

Ives, B., \& Olson, M. H. (1984). User involvement and MIS success: a review of research. Management science, 30(5), 586-603.

Ke, W. \& Zhang, P. (2009). Motivations in OSS Communities: The Mediating Role of Effort Intensity and Goal Commitment. International Journal of Electronic Commerce, 13(4), 39-66.

Kensing, F., \& Blomberg, J. (1998). Participatory design: Issues and concerns. Computer Supported Cooperative Work (CSCW), 7(3-4), 167-185.

Kim, E., \& Lee, J. (1986). An exploratory contingency model of user participation and MIS use. Information \& Management, 11(2), 87-97.

King, W. R., \& He, J. (2005). Understanding the role and methods of meta-analysis in IS research. Communications of the Association for Information Systems, 16(1), 32.

Kujala, S. (2003). User involvement: a review of the benefits and challenges. Behaviour \& information technology, 22(1), 1-16. 
Kujala, S., \& Kauppinen, M. (2004). Identifying and selecting users for user-centered design, Proceedings of the third Nordic conference on Human-computer interaction.

Lakhani, K., \& Wolf, R. (2005). Why Hackers Do What They Do: Understanding Motivation and Effort in Free/Open Source Software Projects. In Feller, J. (Ed.), Perspectives on Free and Open Source Software (pp. 3-21). Cambridge, MA: MIT Press.

Lawrence, M., \& Low, G. (1993). Exploring individual user satisfaction within userled development. MIS Quarterly, 17(2), 195-208.

Leech, N. L., Barrett, K. C. \& Morgan, G. A. (2005). SPSS for Intermediate Statistics, Use and Interpretation. New Jersey: Lawrence Erlbaum Associates Inc.

Lin, W. T., \& Shao, B. B. M. (2000). The relationship between user participation and system success: a simultaneous contingency approach. Information \& Management, 37(6), 283-295.

Lu, H. P., \& Wang, J. Y. (1997). The relationships between management styles, user participation, and system success over MIS growth stages. Information \& Management, 32(4), 203-213.

Maail, A. G., Kurnia, S., \& Chang, S. (2010). A Framework for Exploring Conditional Factors Affecting User Participation in Information Systems Development. Paper presented at the Australasian Conference on Information Systems.

Maiden, N. A. M., \& Rugg, G. (1996). ACRE: selecting methods for requirements acquisition. Software Engineering Journal, 11(3), 183-192.
Mair, P., Hofmann, E., Gruber, K., Hatzinger, R., Zeileis, A., \& Hornik, K. (2014). Motives for Participation in OpenSource Software Projects: A Survey among $R$ Package Authors. Research Report Series. Research Report Series. Institute for Statistics and Mathematics.

Malhotra, N. K., Kim, S. S., \& Patil, A. (2006). Common method variance in IS research: A comparison of alternative approaches and a reanalysis of past research. Management science, 52(12), 18651883.

Mann, H. B., \& Whitney, D. R. (1947). On a test of whether one of two random variables is stochastically larger than the other. The annals of mathematical statistics, 18(1), 50-60.

Mao, J. Y., \& Markus, M. L. (2004). A critical evaluation of user participation research: Gaps and future directions. Paper presented at the Pacific Asia Conference on Information Systems (PACIS 2004).

Markus, M. L. (1983). Power, politics, and MIS implementation. Communications of the ACM, 26(6), 430-444.

Markus, M. L., \& Mao, J. Y. (2004). Participation in development and implementation-updating an old, tired concept for today's IS contexts. Journal of the Association for Information Systems, 5(11), 14.

Mattia, A., \& Weistroffer, H. R. (2008). Information system development: A categorical analysis of user participation approaches. Paper presented at the Proceedings of the 41st Hawaii International Conference on System Sciences, Hawaii, USA.

McKeen, J. D., \& Guimaraes, T. (1997). Successful strategies for user participation in systems development. Journal of Management Information Systems, 14(2), 133-150. 
McKeen, J. D., Guimaraes, T., \& Wetherbe, J. C. (1994). The relationship between user participation and user satisfaction: an investigation of four contingency factors. MIS Quarterly, 18(4), 427-451.

"Motivation". (2017, 26 January 2017). Wikipedia. Retrieved from https://en.wikipedia.org/wiki/Motivation.

Mumford, E. (1979). Consensus systems design: An evaluation of this approach. Design and Implementation of computer based information systems.

Mumford, E. (1981). Participative Systems Design: Structure and Method. Systems, Objectives, Solutions, 1(1), 5-19.

Nasirin, S., Winter, N., \& Coppock, P. (2005). Factors Influencing User Involvement DSS Project Implementation: Some Lessons from the United Kingdom Health Sector. Paper presented at the European Conference on Information Sytems (ECIS).

Nicholls, J. G. (1984). Conceptions of ability and achievement motivation: In Ames, R. \& Ames, C. (Eds.), Research on motivation in education: Student motivation (Vol. 1, pp. 39-73). In: New York: Academic Press.

Norman, D. A. (1986). Cognitive engineering. In User centered system design: New perspectives on humancomputer interaction (pp. 31-65). London: Lawrence Erbaum Associated.

Nunnally, J. C., \& Bernstein, I. H. (1978). Psychometric Theory. New York: McGraw-Hill.

Petter, S., Straub, D., \& Rai, A. (2007). Specifying formative constructs in information systems research. MIS Quarterly, 31(4), 623-656.
Podsakoff, P. M., MacKenzie, S. B., Lee, J. Y., \& Podsakoff, N. P. (2003). Common method biases in behavioral research: a critical review of the literature and recommended remedies. Journal of applied psychology, 88(5), 879-903.

Roberts, J. A., Hann, I. H. \& Slaughter., S. A. (2006). Understanding the motivations, participation, and performance of open source software developers: A longitudinal study of the Apache projects. Management science, 52(7), 984-999.

Rogelberg, S. G., \& Stanton, J. M. (2007). Introduction understanding and dealing with organizational survey nonresponse. Organizational Research Methods, 10(2), 195-209.

Sabherwal, R., Jeyaraj, A., \& Chowa, C. (2006). Information system success: individual and organizational determinants. Management science, 52(12), 1849-1864.

Schuler, D., \& Namioka, A. (1993). Participatory design: Principles and practices. London: Lawrence Erlbaum Associates Inc.

Senn. (1989). Analysis And Design of Information Systems (2nd Edition). New Delhi, India: Tata Mc-graw Hill Publishing.

Shen, K. N., \& Khalifa, M. (2013). When users are professionals: effective user participation for information system assimilation: a multilevel model. Paper presented at the International Conference on Information Systems.

Smith, A., \& Dunckley, L. (2002). Prototype evaluation and redesign: structuring the design space through contextual techniques. Interacting with Computers, 14(6), 821-843.

Spears, J. L., \& Barki, H. (2010). User participation in information systems security risk management. MIS Quarterly, 34(3), 503-522. 
Straub, D., Boudreau, M. C., \& Gefen, D. (2004). Validation guidelines for IS positivist research. The Communications of the Association for Information Systems, 13(1), 380-427.

Strauss, A., \& Corbin, J. (1990). Basics of Qualitative Research: Grounded Theory Procedures and Techniques (Vol. 15): Newbury Park, CA: Sage.

Swanson, E. B. (1974). Management information systems: appreciation and involvement. Management science, 21(2), 178-188.

Symon, G., \& Clegg, C. (2005). Constructing identity and participation during technological change. Human Relations, 58(9), 1141-1166.

Tabachnick, B. G., \& Fidell, L. S. (2001). Using Multivariate Statistics (4th Edition). Boston: Allyn \& Bacon.

Tait, P., \& Vessey, I. (1988). The effect of user involvement on system success: a contingency approach. MIS Quarterly, 91-108.
Treiblmaier, H., \& Filzmoser, P. (2010). Exploratory factor analysis revisited: How robust methods support the detection of hidden multivariate data structures in IS research. Information \& Management, 47(4), 197-207.

Tudhope, D., Beynon-Davies, P., \& Mackay, H. (2000). Prototyping praxis: constructing computer systems and building belief. Human-Computer Interaction, 15(4), 353-383.

Von Hippel, E. (1986). Lead users: a source of novel product concepts. Management science, 32(7), 791-805.

Vroom, V. H. (1964). Work and motivation. New York: Wiley.

Wilson, S., Bekker, M., Johnson, H., \& Johnson, P. (1996). Costs and benefits of user involvement in design: Practitioners' views. In People and Computers XI (pp. 221-240): Springer. 


\section{Appendix}

\section{Part 1: Select Measurement Items}

This reports the questions used in assessment of user participation motives and project outcome in the survey instrument. The actual survey questionnaire had identical structure excluding the leftmost ID column.

\section{(5: Strongly Agree, 4: Agree, 3: Neutral, 2: Disagree, 1: Strongly Disagree)}

\begin{tabular}{|c|c|c|}
\hline PSC & $\begin{array}{l}\text { My participation was in accordance with my commitments as member of the project } \\
\text { steering committee. }\end{array}$ & 54321 \\
\hline$A D$ & $\begin{array}{l}\text { My participation was in accordance with the directive passed to me by the } \\
\text { authority. }\end{array}$ & 54321 \\
\hline TUM & $\begin{array}{l}\text { I participated in order to mediate between the development team and users during } \\
\text { project execution. }\end{array}$ & 54321 \\
\hline $\mathrm{RF}$ & I participated in order to finalize the requirements of the project. & 54321 \\
\hline PDT & $\begin{array}{l}\text { I participated as I was already a part of the project team which developed the } \\
\text { software. }\end{array}$ & 54321 \\
\hline GSI & $\begin{array}{l}\text { I participated in order to generate the inputs required by the software that was } \\
\text { under development. }\end{array}$ & 54321 \\
\hline OD & I participated in order to oversee that the software gets developed. & 54321 \\
\hline ATA & I participated in order to facilitate the acceptance testing process in the project. & 54321 \\
\hline ITU & $\begin{array}{l}\text { I participated in order to introduce other users in my organization to the project } \\
\text { development team. }\end{array}$ & 54321 \\
\hline TU & I participated in order to train other users in learning the software. & 54321 \\
\hline FF & $\begin{array}{l}\text { I participated in order to provide feedback on the project's development status to } \\
\text { other users in my organization. }\end{array}$ & 54321 \\
\hline TCD & $\begin{array}{l}\text { I participated in order to assist other users in my organization in designing test } \\
\text { cases. }\end{array}$ & 54321 \\
\hline OS & I am generally interested in operating the software. & 54321 \\
\hline OrC & I am generally interested to see changes happening in the organization. & 54321 \\
\hline SPR & I participated as the outcome of this project is personally relevant to me. & 54321 \\
\hline $\mathrm{CO}$ & I participated as the project is critical to the needs of my organization. & 54321 \\
\hline DwT & $\begin{array}{l}\text { I participated as and when the development team included me in their discussion } \\
\text { on relevant issues related to the project under consideration. }\end{array}$ & 54321 \\
\hline Gll & I participated as I am generally interested in information technology projects. & 54321 \\
\hline CJ & I participated as the project is critical with respect to my job/career needs. & 54321 \\
\hline USO & $\begin{array}{l}\text { I participated in order to use the output of the software or modules that were being } \\
\text { developed in the course of project execution. }\end{array}$ & 54321 \\
\hline
\end{tabular}




\begin{tabular}{|c|l|l|}
\hline $\mathrm{NI}$ & I participated as I was needed during the need identification stage of the project. & 54321 \\
\hline $\mathrm{Dn}$ & I participated as I was needed during the design stage of the project. & 54321 \\
\hline $\mathrm{FA}$ & I participated as I was needed during the functional analysis stage of the project. & 54321 \\
\hline IA & $\begin{array}{l}\text { I participated as I was needed during the installation and acceptance stage of the } \\
\text { project. }\end{array}$ & 54321 \\
\hline
\end{tabular}

The following statements describe various aspects of assessing project outcomes from a project user's perceptive. For each, please indicate your level of agreement by circling one number, in the right column.

(5: Strongly Agree, 4: Agree, 3: Neutral, 2: Disagree, 1: Strongly Disagree)

\begin{tabular}{|c|c|c|}
\hline $\mathrm{HI}$ & I am satisfied with the way help and other operational instructions were provided. & 54321 \\
\hline OpC & $\begin{array}{l}\text { I am satisfied with the accuracy of the software output (i.e. query answers, report } \\
\text { figures etc.) }\end{array}$ & 54321 \\
\hline SOP & I am satisfied with the efficiency and operational performance of the software. & 54321 \\
\hline DDA & I am satisfied with the way delivery deadlines were met by the project organization. & 54321 \\
\hline TPA & $\begin{array}{l}\text { I am satisfied with the way the project organization integrated the third party co- } \\
\text { ordination activities in its project schedule. }\end{array}$ & 54321 \\
\hline AP & $\begin{array}{l}\text { I am satisfied with the procedures followed in relation to the acceptance of different } \\
\text { project artifacts. }\end{array}$ & 54321 \\
\hline $\mathrm{TL}$ & $\begin{array}{l}\text { I am satisfied with the level of transparency shown in relation to the progress and } \\
\text { control of the project. }\end{array}$ & 54321 \\
\hline EV & $\begin{array}{l}\text { I am satisfied with the visibility of project execution (consider period communication } \\
\text { of status, etc.) }\end{array}$ & 54321 \\
\hline CS & I am satisfied with the way settlement of claims was handled. & 54321 \\
\hline PP & I am satisfied with the way project planning was carried out. & 54321 \\
\hline SEO & $\begin{array}{l}\text { I am satisfied with the way organization of social events, if any, at major project } \\
\text { milestones was managed. }\end{array}$ & 54321 \\
\hline EUC & $\begin{array}{l}\text { I am satisfied with the way communication with the project end-users was } \\
\text { managed. }\end{array}$ & 54321 \\
\hline SCC & $\begin{array}{l}\text { I am satisfied with the way communication of project issues with the steering } \\
\text { committee was managed. }\end{array}$ & 54321 \\
\hline $\mathrm{CH}$ & $\begin{array}{l}\text { I am satisfied with the way communication of project completion procedures with } \\
\text { stakeholders occurred. }\end{array}$ & 54321 \\
\hline $\mathrm{CDH}$ & $\begin{array}{l}\text { I am satisfied with the way crisis and disaster affecting the project, if any, was } \\
\text { handled. }\end{array}$ & 54321 \\
\hline $\mathrm{HM}$ & $\begin{array}{l}\text { I am satisfied with the way project meetings were handled (consider preparation, } \\
\text { presentations etc.) }\end{array}$ & 54321 \\
\hline
\end{tabular}




\begin{tabular}{|c|l|l|}
\hline UEM & $\begin{array}{l}\text { I am satisfied with the management of unforeseen events (if any) by the project } \\
\text { organization during execution of the project. }\end{array}$ & 54321 \\
\hline CIP & I am satisfied with the way pricing of claims was carried out. & 54321 \\
\hline ChP & I am satisfied with the way pricing of changes to project scope was carried out. & 54321 \\
\hline CEA & I am satisfied with the way the project organization adhered to the cost estimates. & 54321 \\
\hline MA & $\begin{array}{l}\text { I am satisfied with the way the project organization was able to cater to the different } \\
\text { milestones while the project was in progress. }\end{array}$ & 54321 \\
\hline
\end{tabular}

\section{Part 2: User Organization Maturity Levels}

\begin{tabular}{|c|c|}
\hline Level \# & Description \\
\hline 1 & Not yet started or minimal efforts at best. \\
\hline 2 & $\begin{array}{l}\text { Early stage of operation; some activities underway but standardized approaches just } \\
\text { emerging; inconsistent management support. }\end{array}$ \\
\hline 3 & $\begin{array}{l}\text { Viable processes and resources becoming more effective through experience; consistent } \\
\text { management support. }\end{array}$ \\
\hline 4 & $\begin{array}{l}\text { Mature practices and resources proven effective for many scenarios; deep management } \\
\text { commitment. }\end{array}$ \\
\hline 5 & $\begin{array}{l}\text { World-class practices and resources, highly refined and adaptable; deeply embedded in } \\
\text { organization's culture. }\end{array}$ \\
\hline
\end{tabular}

\section{About the Author}

Rahul Thakurta is a faculty in information systems (IS) at Xavier Institute of Management Bhubaneswar (XIMB), Xavier University, India. He received his Fellowship in Management Information Systems from Indian Institute of Management Calcutta. He teaches courses pertaining to information systems and operations management disciplines. His broad research interests include areas like planning and implementation of IS infrastructures, management of software ventures and technology adoption and diffusion. He has been the recipient of Infosys Research Fellowship and DAAD Short Term Research Scholarship. 